Article

\title{
Biomass, Carbon and Nutrient Storage in a 30-Year-Old Chinese Cork Oak (Quercus Variabilis) Forest on the South Slope of the Qinling Mountains, China
}

\author{
Yang Cao ${ }^{1,2}$ and Yunming Chen ${ }^{1,2, *}$
}

1 State Key Laboratory of Soil Erosion and Dryland Farming on the Loess Plateau, Northwest A \& F University, Yangling 712100, China; E-Mail: yang.cao@nwsuaf.edu.cn

2 Institute of Soil and Water Conservation, Chinese Academy of Sciences and Ministry of Water Resources, Yangling 712100, China

* Author to whom correspondence should be addressed; E-Mail: ymchen@ms.iswc.ac.cn; Tel./Fax: +86-29-8701-4869.

Academic Editors: Heinz Rennenberg and Mark A. Adams

Received: 5 December 2014 / Accepted: 13 April 2015 / Published: 21 April 2015

\begin{abstract}
Chinese cork oak (Quercus variabilis) forests are protected on a large-scale under the Natural Forest Protection (NFP) program in China to improve the ecological environment. However, information about carbon (C) storage to increase $\mathrm{C}$ sequestration and sustainable management is lacking. Biomass, $\mathrm{C}$, nitrogen $(\mathrm{N})$ and phosphorus $(\mathrm{P})$ storage of trees, shrubs, herb, litter and soil $(0-100 \mathrm{~cm})$ were determined from destructive tree sampling and plot level investigation in approximately 30-year old Chinese cork oak forests on the south slope of the Qinling Mountains. There was no significant difference in tree components' biomass estimation, with the exception of roots, among the available allometric equations developed from this study site and other previous study sites. Leaves had the highest $\mathrm{C}, \mathrm{N}$ and $\mathrm{P}$ concentrations among tree components and stems were the major compartments for tree biomass, $\mathrm{C}, \mathrm{N}$ and $\mathrm{P}$ storage. In contrast to finding no difference in $\mathrm{N}$ concentrations along the whole soil profile, higher $\mathrm{C}$ and $\mathrm{P}$ concentrations were observed in the upper $0-10 \mathrm{~cm}$ of soil than in the deeper soil layers. The ecosystem C, N, and P storage was 163.76, 18.54 and $2.50 \mathrm{t} \mathrm{ha}^{-1}$, respectively. Soil $(0-100 \mathrm{~cm})$ contained the largest amount of $\mathrm{C}, \mathrm{N}$ and P storage, accounting for $61.76 \%, 92.78 \%$ and $99.72 \%$ of the total ecosystem, followed by $36.14 \%, 6.03 \%$ and $0.23 \%$ for trees, and $2.10 \%, 1.19 \%$ and $0.03 \%$ for shrubs, herbs and litter, respectively. The equations accurately estimate ecosystem biomass, and the
\end{abstract}


knowledge of the distribution of $\mathrm{C}, \mathrm{N}$ and $\mathrm{P}$ storage will contribute to increased $\mathrm{C}$ sequestration and sustainable management of Chinese cork oak forests under the NFP program.

Keywords: biomass allocation; carbon concentration; nutrient element; Natural Forest Protection (NFP) program

\section{Introduction}

Protecting existing forests and planting new forests through reforestation and afforestation are important measures to enhance carbon (C) sequestration capacity and potential in terrestrial ecosystems [1-4]. A growing number of studies have addressed $C$ storage and sequestration in key national ecological restoration programs in China, such as the Sloping Land Conversion program, Three-North Sheltbelt Forest program, Changjiang (Yangtze) River Basin Forest Protection program, Beijing-Tianjin Sandstorm Source Control program, Natural Forest Protection program (NFP), and other programs [2,5-9].

The NFP program was implemented in 1998 with the goal of promoting natural forest resource protection and cultivation to improve the ecological environment, has been implemented since 1998 [6,10]. It covers about $6.0 \times 10^{7}$ ha of natural forest land, which accounts for $50 \%$ of the total natural forest area within 17 provincial-level administrative units in China [10]. Hu and Liu [11] used the volume-biomass method and National Forestry Statistics to calculate C storage of the NFP program from 1998-2002 and found that in total it sequestered 44.07 Tg, including 21.32 $\mathrm{Tg}$ from reforestation and afforestation, and $22.75 \mathrm{Tg}$ from reduced the timber production. The results of Wei et al. [10] showed that the tree C pool under the NFP program in northeastern China increased from 1998 to 2008, by $6.3 \mathrm{Tg} \mathrm{C}$, which was mainly sequestrated by natural forests $\left(5.1 \mathrm{Tg} \mathrm{C}^{\mathrm{Cear}}{ }^{-1}\right)$. It has been projected that biomass $\mathrm{C}$ storage from afforestation under the NFP program could potentially increase from $33.67 \mathrm{Tg}$ in 2011 to $96.03 \mathrm{Tg}$ in 2020 [6]. However, most of these previous studies were mainly conducted on forest biomass $\mathrm{C}$ storage at the national and regional scales with different estimation methods and different forest resource data. Moreover, there are few precise studies concerning direct plot investigations for various forest types, $\mathrm{C}$ storage estimates that include understory, forest floor, and soil, and the relationship between climatic factors and forest types on regional scales [12-16]. An age-related study on $\mathrm{C}$ storage in a black locust forest ecosystem on the Loess Plateau showed that tree $\mathrm{C}$ storage increased from 5 to 38 years, but significantly decreased from 38 to 56 years owing to high tree mortality. Moreover, storage in the shrub layer increased with stand age, but it was age-independent in the herb layer and litter. Storage in the topsoil $(0-20 \mathrm{~cm})$ increased at a constant rate with stand age, while it was age-independent in sub-top soil [7]. With an increased numbers of local studies, we can gain a more comprehensive understanding of the complex nature of ecosystem $\mathrm{C}$ storage in order to scale up to regional and global levels.

Quercus species are a keystone species in a wide range of habitats from Mediterranean semi-desert woodlands to subtropical rainforest in Europe, North America, and Southeast Asia [17]. For example, the cork oak is the second most important Portuguese forest species both in terms of the country forest 
area and in terms of forest industry product exports [18]. Many studies have explored the temporal and spatial distribution of biomass and nutrient accumulation in Quercus species for suitable management and conservation, especially in Spain and Portugal [17-26]. Guyette, Dey and Stambaugh [17] documented the temporal distribution in C storage of oak wood at floodplains in northern Missouri, USA. In this study, we chose Chinese cork oak (Quercus variabilis) as a model system to carefully evaluate biomass and nutrient pools in different ecosystem components. Chinese cork oak is one of the major Quercus species in warm-temperate and subtropical forests, ranging from $22^{\circ}-42^{\circ} \mathrm{N}$ to $99^{\circ}-122^{\circ} \mathrm{E}$. There were only a few studies that developed allometric equations (Table 1; Equations (1)-(3)) and addressed tree biomass allocation of Chinese cork oak in different sites in China [27-29]. The Qinling Mountains in the Shanxi Province is one of the major distribution areas of Chinese cork oak forests. Chinese cork oak forests in the Qinling Mountains make up the largest forest vegetation carbon sink based on the Shanxi Province forest resource inventory data. However, these forests have been under serious threat owing to excessive overexploitation and inappropriate management for timber and charcoal production, cultivation of edible wild mushrooms, and dye products. Therefore, many studies have been conducted to provide some recommendations toward sustainable management of the Chinese cork oak forests in the Qinling Mountains under the NFP program [30-33]. However, there is still a lack of information about C stocks, especially below-ground, for Chinese cork oak forests in the Qinling Mountain, China.

The focus of this study was to develop suitable allometric equations to calculate various tree biomass components, and to quantify the distribution patterns and quantities of $\mathrm{C}, \mathrm{N}$, and $\mathrm{P}$ among the major tree components, shrubs, herbs, litter, and soil $(0-100 \mathrm{~cm})$ in Chinese cork oak forest along the south slope of the Qinling Mountains. Results of this study may provide a crucial complement to previous studies on the understanding of $\mathrm{C}$ storage and forest management under the NFP program.

\section{Materials and Methods}

\subsection{Study Site and Sampling}

This study was conducted in the Shan Yang Country, Southern Shanxi Province, China $\left(33^{\circ} 09^{\prime}-33^{\circ} 42^{\prime} \mathrm{N}\right.$, $109^{\circ} 32^{\prime}-110^{\circ} 29^{\prime}$ E; Figure 1). The Shan Yang Country is located on the south slope of the Qinling Mountains, China. The study area is situated in the transitional area between the subtropical zone and the warm temperate zone, with a mean annual temperature $13.1{ }^{\circ} \mathrm{C}$, a mean annual rainfall of $709 \mathrm{~mm}$, and a mean frost-free period of 207 days. Forest coverage is $62.6 \%$, and more than $80 \%$ of the forest area is dominated by pure Chinese cork oak forest, which originated from seedlings, with a few Sabina chinensis, and Pinus armandii species. Shrub species at the site include Pyrus betulifolia, Lespedeza bicolor, and Platycarya strobilacea, and the main herb species are Carextristachya, Imperata cylindrical and Ophiopogon japonicas. 
Table 1. Collection of the available allometric equations used to calculate biomass of the various tree components for Chinese cork oak forests in China.

\begin{tabular}{|c|c|c|c|c|c|c|}
\hline NO. & Site & Stand $^{\mathrm{a}}$ & Components & Allometric equation & $\begin{array}{c}\text { Correlation } \\
\text { coefficient }(R)\end{array}$ & Sources \\
\hline 1. & $\begin{array}{l}\text { Xiaolong Mountains, } \\
\text { Gansu Province } \\
\left(33^{\circ} 30^{\prime}-34^{\circ} 49^{\prime} \mathrm{N},\right. \\
\left.104^{\circ} 22^{\prime}-106^{\circ} 43^{\prime} \mathrm{E}\right)\end{array}$ & $\begin{array}{c}20-84 \\
6.0-18.6 \\
4.3-13.1\end{array}$ & $\begin{array}{l}\text { Stem wood } \\
\text { Stem bark } \\
\text { Branches } \\
\text { Leaves } \\
\text { Roots }\end{array}$ & $\begin{aligned} \operatorname{LnW}_{\mathrm{S}} & =-3.7447+0.9679 \operatorname{Ln}\left(\mathrm{DBH}^{2} \mathrm{H}\right) \\
\operatorname{LnW}_{\mathrm{BA}} & =-3.2565+0.7156 \mathrm{Ln}\left(\mathrm{DBH}^{2} \mathrm{H}\right) \\
\mathrm{LnW}_{\mathrm{BR}} & =-4.8449+1.0013 \mathrm{Ln}\left(\mathrm{DBH}^{2} \mathrm{H}\right) \\
\mathrm{LnW}_{\mathrm{L}} & =-3.3569+0.6050 \mathrm{Ln}\left(\mathrm{DBH}^{2} \mathrm{H}\right) \\
\mathrm{LnW}_{\mathrm{R}} & =-2.9066+0.8144 \mathrm{Ln}\left(\mathrm{DBH}^{2} \mathrm{H}\right)\end{aligned}$ & $\begin{array}{l}0.9981 \\
0.9852 \\
0.9917 \\
0.9611 \\
0.9941\end{array}$ & [28] \\
\hline 2. & $\begin{array}{l}\text { Baotianman Natural } \\
\text { Reserve, Henan } \\
\text { Province } \\
\left(33^{\circ} 25^{\prime}-33^{\circ} 33^{\prime} \mathrm{N}\right. \\
\left.111^{\circ} 53^{\prime}-112^{\circ} \mathrm{E}\right)\end{array}$ & $\begin{array}{c}45 \\
6.0-30.5 \\
8.3-18.5\end{array}$ & $\begin{array}{l}\text { Stem wood } \\
\text { Stem bark } \\
\text { Branches } \\
\text { Leaves } \\
\text { Roots }\end{array}$ & $\begin{array}{c}\operatorname{LgW}_{\mathrm{S}}=-0.5440+0.6796 \mathrm{Lg}\left(\mathrm{DBH}^{2} \mathrm{H}\right) \\
\mathrm{LgW}_{\mathrm{BA}}=-0.8246+0.5896 \mathrm{Lg}\left(\mathrm{DBH}^{2} \mathrm{H}\right) \\
\mathrm{LgW}_{\mathrm{BR}}=-2.5609+1.1092 \mathrm{Lg}\left(\mathrm{DBH}^{2} \mathrm{H}\right) \\
\mathrm{LgW}_{\mathrm{L}}=-2.0038+0.7460 \mathrm{Lg}\left(\mathrm{DBH}^{2} \mathrm{H}\right) \\
\mathrm{LgW}_{\mathrm{R}}=-0.2645+0.5173 \mathrm{Lg}\left(\mathrm{DBH}^{2} \mathrm{H}\right)\end{array}$ & $\begin{array}{l}0.9969 \\
0.9983 \\
0.9750 \\
0.9851 \\
0.9986\end{array}$ & [27] \\
\hline 3. & $\begin{array}{c}\text { Xishan Mountains, } \\
\text { Beijing }\left(39^{\circ} 34^{\prime} \mathrm{N},\right. \\
\left.116^{\circ} 28^{\prime} \mathrm{E}\right)\end{array}$ & $\begin{array}{c}26 \\
3.1-10.3 \\
6.0-8.0\end{array}$ & $\begin{array}{l}\text { Stems } \\
\text { Branches } \\
\text { Leaves } \\
\text { Roots }\end{array}$ & $\begin{array}{l}\mathrm{W}_{\mathrm{S}+\mathrm{BA}}=0.0508\left(\mathrm{DBH}^{2} \mathrm{H}\right)^{0.92} \\
\mathrm{~W}_{\mathrm{BR}}=0.0197\left(\mathrm{DBH}^{2} \mathrm{H}\right)^{0.8944} \\
\mathrm{~W}_{\mathrm{L}}=0.0029\left(\mathrm{DBH}^{2} \mathrm{H}\right)^{0.9125} \\
\mathrm{~W}_{\mathrm{R}}=0.0458\left(\mathrm{DBH}^{2} \mathrm{H}\right)^{0.7484}\end{array}$ & $\begin{array}{l}0.9889 \\
0.9412 \\
0.9557 \\
0.9485\end{array}$ & [29] \\
\hline 4. & $\begin{array}{l}\text { Shanyang Country, } \\
\text { Shanxi Province } \\
\left(33^{\circ} 9^{\prime}-34^{\circ} 42^{\prime} \mathrm{N},\right. \\
\left.109^{\circ} 32^{\prime}-110^{\circ} 29^{\prime} \mathrm{E}\right)\end{array}$ & $\begin{array}{c}30 \\
5.0-34.2 \\
4.0-15.0\end{array}$ & $\begin{array}{l}\text { Stem wood } \\
\text { Stem bark } \\
\text { Branches } \\
\text { Leaves } \\
\text { Roots }\end{array}$ & $\begin{array}{c}\mathrm{W}_{\mathrm{S}}=0.0335\left(\mathrm{DBH}^{2} \mathrm{H}\right)^{0.9579} \\
\mathrm{~W}_{\mathrm{BA}}=0.0458 \mathrm{DBH}^{2.1044} \\
\mathrm{~W}_{\mathrm{BR}}=0.0047 \mathrm{DBH}^{2.9836} \\
\mathrm{~W}_{\mathrm{L}}=0.0128 \mathrm{DBH}^{2.1013} \\
\mathrm{~W}_{\mathrm{R}}=0.0831 \mathrm{DBH}^{2.1980}\end{array}$ & $\begin{array}{l}0.9949 \\
0.9836 \\
0.9830 \\
0.9916 \\
0.9634\end{array}$ & This study \\
\hline
\end{tabular}

${ }^{a}$ referring to stand age (year), DBH $(\mathrm{cm})$ and $\mathrm{H}(\mathrm{m})$, respectively. 


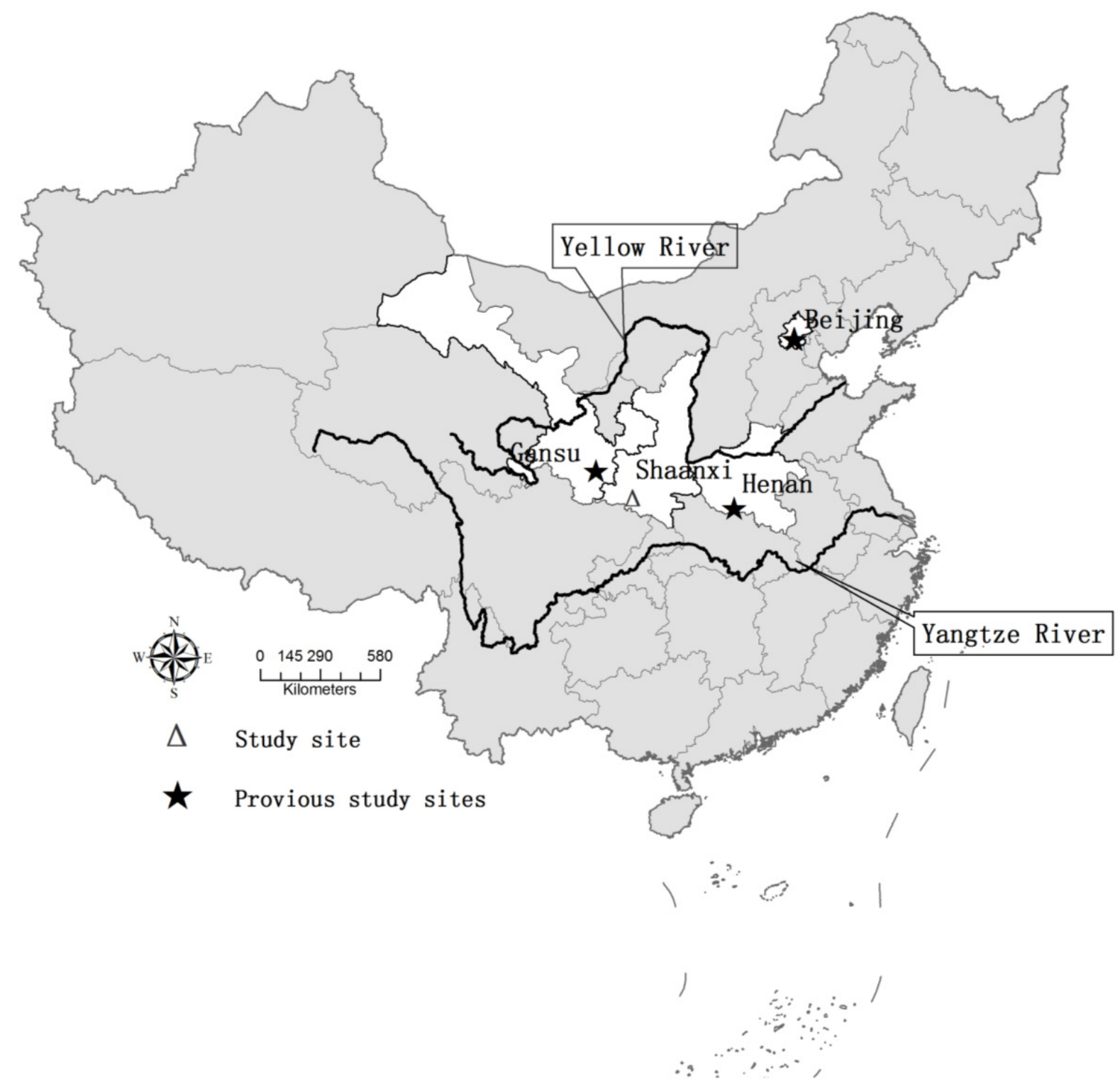

Figure 1. Site distribution of studies on Chinese cork oak allometric equations include Xiaolong Mountains, Gansu Province; the Xishan Mountains, Beijing; the Baotianman Natural Reserve, Henan Province; and the present study at Shanyang Country, Shanxi Province.

With the guidance of local forestry bureau staff, three widely distributed Chinese cork oak stands with similar site conditions, little or no human disturbance, and approximately 30 years old were selected under from the Shan Yang Country. The sites were all located near the middle of slopes and there was little difference among the sites with regard to aspect (North West), gradient (30-35 $)$, and elevation $(845-1068 \mathrm{~m})$. The distance between each stand was about 5-8 km. Historically, all study stands naturally regenerated after the natural Chinese cork oaks were harvested. A $20 \mathrm{~m} \times 20 \mathrm{~m}$ plot was constructed in the central area of each stand for sampling. Diameter at breast height (DBH) and height (H) were measured for all trees $(\mathrm{DBH} \geq 5.0 \mathrm{~cm})$ in each plot. In early August 2013, five Chinese cork oak trees within representative stand-specific DBH range were selected and harvested destructively in each stand following a previously published harvest method [19,27-29,34-36]. Trees were cut near the ground surface, after measurement of the total $\mathrm{H}$ of each tree, the tree stem was first cut open at $1.3 \mathrm{~m}$, 
and then the top part of stem (from $1.3 \mathrm{~m}$ to the tips) was divided into 1-m-long sections. All branches and leaves of each stem section were clipped from the tree stems and branches, respectively and weighed. Stem discs ( $5 \mathrm{~cm}$ thickness) were collected from of each section, and the stem bark was separated from each disc to measure the weight of the fresh stem bark and the stem wood without bark. The whole root system was manually excavated, washed lightly to remove soil particles, and weighed.

Shrub and herb biomass was determined using total harvesting destructive sampling techniques [34]. Sampling of the shrub layer and herb layer was conducted in five $2 \mathrm{~m} \times 2 \mathrm{~m}$ subplots and $1 \mathrm{~m} \times 1 \mathrm{~m}$ subplots, respectively. These subplots were randomly selected within each plot. Shrub plants were separated into leaves, stems and roots, and herbs were separated into aboveground and belowground components. Litter was sampled by collecting the entire organic material within five $1 \mathrm{~m} \times 1 \mathrm{~m}$ subplots randomly chosen in each plot [34].

Subsamples of tree components (stem wood, stem bark, branches, foliage, and roots), shrub (leaves, stems and roots), herb (above- and belowground) and litter were sealed in plastic bags, and then oven dried at $80{ }^{\circ} \mathrm{C}$ in the laboratory to constant weight to obtain wet-to-dry mass conversion factors. The dried samples were ground and used to determine plant $\mathrm{C}$ and $\mathrm{N}$ concentrations by an elemental analyzer (Carlo Erba 1106, Milan, Italy). Total $\mathrm{P}$ was determined by the $\mathrm{HClO}_{4}-\mathrm{H}_{2} \mathrm{SO}_{4}$ colorimetric method [37].

In each plot, five soil cores ( $5 \mathrm{~cm}$ in diameter) were randomly collected at $0-10 \mathrm{~cm}, 10-20 \mathrm{~cm}$, 20-30 cm, 30-50 cm and 50-100 cm layers. After removing the plant roots, fauna and debris by hand, the soil was air dried at room temperature around $20{ }^{\circ} \mathrm{C}$, and then ground and passed through a $0.25 \mathrm{~mm}$ sieve for determination of soil chemical properties. $\mathrm{C}$ concentration was determined by the $\mathrm{K}_{2} \mathrm{Cr}_{2} \mathrm{O}_{7}-\mathrm{H}_{2} \mathrm{SO}_{4}$ method [38], total $\mathrm{N}$ concentration by the Kjeldahl method [39] and total $\mathrm{P}$ by the $\mathrm{HClO}_{4}-\mathrm{H}_{2} \mathrm{SO}_{4}$ colorimetric method [37].A soil profile $(1 \mathrm{~m} \times 1 \mathrm{~m} \times 1 \mathrm{~m})$ in each plot was dug for measuring soil bulk density $\left(\mathrm{g} \mathrm{cm}^{-3}\right)$. After excluding recognizable soil surface litter, stainless cutting rings $\left(5 \mathrm{~cm}\right.$ in diameter) were used to sample five replicated $100 \mathrm{~cm}^{3}$ of soil at each layer at same depth intervals of $0-10 \mathrm{~cm}, 10-20 \mathrm{~cm}, 20-30 \mathrm{~cm}, 30-50 \mathrm{~cm}$ and $50-100 \mathrm{~cm}$ layers. The ring soil samples were scraped out and roots manually removed. The soils were dried at $105^{\circ} \mathrm{C}$ to constant weight to calculate bulk density (oven-dried soil sample/volume of the metal ring). All of the samples were analyzed at the central laboratory of the Institute of Soil and Water Conservation, Chinese Academy of Sciences and Ministry of Water Resources (Yangling, China).

\subsection{Data Calculation and Analysis}

Before establishing the allometric equation, scatter plots were used to visualize whether the relationship between the independent (dry biomass $(\mathrm{kg})$ of each tree component) and dependent variables (DBH and/or $\mathrm{H}$ of each tree) was linear. A power function was selected as an appropriate model in this study, with the following equations:

$$
\begin{gathered}
\mathrm{W}=\mathrm{aDBH} \mathrm{H}^{\mathrm{b}} \\
\mathrm{W}=\mathrm{a}\left(\mathrm{DBH}^{2} \times \mathrm{H}\right)^{\mathrm{b}}
\end{gathered}
$$

where $\mathrm{W}$ is the dry biomass $(\mathrm{kg})$ of each tree component; $\mathrm{a}$ and $\mathrm{b}$ are allometric parameters; least squares linear regression was used to estimate the value of a and b. Ordinary least squares regression was performed to determine the coefficient of determination $(R)$. 
The developed allometric equations from this study (Table 1; Equations (4)) and the available allometric equations (Table 1; Equations (1)-(3)) developed previously in other study sites (Figure 1) were used to compare the differences in tree biomass (stem wood, stem bark, branches, leaves, and roots) estimations. Then, the total ecosystem $\mathrm{C}, \mathrm{N}$ and $\mathrm{P}$ storage in the present study site were calculated based on the combination of tree (stem wood, stem bark, branches, leaves, and roots), shrub (leaves, stem and roots), herbs (above- and belowground), litter layers, and soil $(0-100 \mathrm{~cm})$ pools. C, N, and P concentrations of leaves, branches, stem bark, stem wood, and roots were multiplied by each tree component biomass from the developed species-specific allometric equations from the present site (Table 1, Equation (4)) to partition C, N, and P stocks among the tree components, and then summed the stocks for each tree and site to calculate the stand level stocks. For shrubs, herbs and litter, the C, N, and $\mathrm{P}$ concentrations were multiplied by their component mass at the plot level to calculate the stand level $\mathrm{C}, \mathrm{N}$ and $\mathrm{P}$ stocks. The stock of soil $\mathrm{C}, \mathrm{N}$, and $\mathrm{P}$ in the different layers of soil were calculated by multiplying the soil bulk density with soil depth and $\mathrm{C}, \mathrm{N}$, and $\mathrm{P}$ concentrations in each layer. The carbon storage results in each layer of soil $(0-10 \mathrm{~cm}, 10-20 \mathrm{~cm}, 20-30 \mathrm{~cm}, 30-50 \mathrm{~cm}$ and $50-100 \mathrm{~cm})$ were then summed to compute the total $\mathrm{C}, \mathrm{N}$, and $\mathrm{P}$ storage to a depth of $100 \mathrm{~cm}$.

All statistical analyses were performed with SPSS (version 20.0, SPSS Inc., Chicago, IL, USA) and the accepted significance level was $\alpha=0.05$. Allometric equations were developed with linear regression. Goodness of fit was based on the coefficient of determination $(R)$ and the level of probability $(p)$. All comparisons of biomass among the different allometric equations were performed using ANOVA, followed by multiple comparisons (LSD tests).

\section{Results}

\section{Allometric Equations and Tree Biomass}

The allometric equations developed in this study were all power functions (Table 1). Only significant parameters were included in the equations; therefore, DBH was the only significant parameter for bark, leaves, and roots components. DBH squared multiplied H was the significant parameter for stem wood. All equations had significant linear relationships between dependent and independent variables, and their correlation coefficients ranged from 0.9634 to 0.9949 (Table 1).

Although allometric equations of different forms are available from the present and previous studies, there was no significant difference in the biomass estimation for the various tree components in this study, with the exception of roots (Table 2). The root biomass calculated by the equation of Bao et al. [19] was significantly lower $\left(17.59 \mathrm{t} \mathrm{ha}^{-1}\right)$ than the values generated by the other equations. Therefore, biomass from other equations was distributed similarly in the following manner: stem wood $>$ roots $>$ branches $>$ stem bark $>$ leaves. According to the tree biomass distribution pattern in the present sites, stem wood made the largest contribution to the total tree biomass, accounting for around $50 \%$, while the proportion of leaves to total tree biomass was only around 3\%, and the ratio of below- to aboveground was 0.33 (Table 2). 
Table 2. Comparison of the biomass estimates of the various tree components by different allometric equations for a Chinese cork oak forest in the south slope of the Qinling Mountains, China.

\begin{tabular}{|c|c|c|c|c|c|c|c|c|}
\hline \multirow{2}{*}{$\begin{array}{c}\text { Tree } \\
\text { component }\end{array}$} & \multicolumn{2}{|c|}{ Allometric Equations (1) [28] } & \multicolumn{2}{|c|}{ Allometric Equations (2) [27] } & \multicolumn{2}{|c|}{ Allometric Equations (3) [29] } & \multicolumn{2}{|c|}{$\begin{array}{c}\text { Allometric Equations (4) } \\
\text { (This Study) }\end{array}$} \\
\hline & $\begin{array}{l}\text { Biomass } \\
\left(\mathrm{t} \mathrm{ha}^{-1}\right)\end{array}$ & $\begin{array}{l}\text { Proportion } \\
(\%)\end{array}$ & $\begin{array}{c}\text { Biomass } \\
\left(\mathrm{t} \mathrm{ha}^{-1}\right)\end{array}$ & $\begin{array}{l}\text { Proportion } \\
(\%)\end{array}$ & Biomass $\left(\mathrm{t} \mathrm{ha}^{-1}\right)$ & $\begin{array}{c}\text { Proportion } \\
(\%)\end{array}$ & $\begin{array}{c}\text { Biomass } \\
\left(\mathrm{t} \mathrm{ha}^{-1}\right)\end{array}$ & $\begin{array}{c}\text { Proportion } \\
(\%)\end{array}$ \\
\hline Stem wood & $50.56 \pm 4.97 \mathrm{a}$ & 40.96 & $64.53 \pm 5.16 \mathrm{a}$ & 46.42 & & & $66.20 \pm 6.46 a$ & 49.13 \\
\hline Stem bark & $11.48 \pm 0.94 \mathrm{a}$ & 9.30 & $16.99 \pm 1.28 \mathrm{a}$ & 12.22 & & & $14.48 \pm 1.12 \mathrm{a}$ & 10.75 \\
\hline Stem & $62.05 \pm 5.89 \mathrm{a}$ & 50.26 & $81.54 \pm 6.44 a$ & 58.65 & $74.46 \pm 7.06 \mathrm{a}$ & 62.22 & $80.68 \pm 7.54 \mathrm{a}$ & 59.87 \\
\hline Branches & $21.92 \pm 2.21 \mathrm{a}$ & 17.76 & $18.07 \pm 1.98 \mathrm{a}$ & 13.00 & $23.61 \pm 2.19 \mathrm{a}$ & 19.73 & $16.30 \pm 1.64 \mathrm{a}$ & 12.10 \\
\hline Leaves & $4.45 \pm 0.34 \mathrm{a}$ & 3.60 & $3.74 \pm 0.31 \mathrm{a}$ & 2.70 & $4.01 \pm 0.38 \mathrm{a}$ & 3.35 & $4.01 \pm 0.31 \mathrm{a}$ & 2.98 \\
\hline Aboveground & $88.41 \pm 8.42 \mathrm{a}$ & 71.62 & $103.35 \pm 8.61 \mathrm{a}$ & 74.34 & $102.08 \pm 9.63 \mathrm{a}$ & 85.30 & $100.99 \pm 9.47 \mathrm{a}$ & 74.95 \\
\hline Root & $35.05 \pm 3.07 \mathrm{a}$ & 28.39 & $35.67 \pm 2.59 \mathrm{a}$ & 25.66 & $17.59 \pm 1.47 \mathrm{~b}$ & 14.70 & $33.76 \pm 2.68 \mathrm{a}$ & 25.05 \\
\hline Total tree & $123.45 \pm 11.48 \mathrm{a}$ & & $139.02 \pm 11.14 \mathrm{a}$ & & $119.67 \pm 11.09 \mathrm{a}$ & & $134.75 \pm 12.11 \mathrm{a}$ & \\
\hline
\end{tabular}

Data is reported as mean \pm standard error $(n=3)$; within a line, values followed by the same lowercase letter indicate that the estimated biomass of the same tree component did not differ significantly among different allometric equations $(p<0.05)$. 
Higher $\mathrm{C}, \mathrm{N}$, and $\mathrm{P}$ concentrations were observed in the shrub leaves than in shrub roots (Table 3). Similarly, the $\mathrm{C}$ and $\mathrm{N}$ concentrations in aboveground herbs were significantly higher than in belowground herbs (Table 3). The C:N and C:P mass ratios in shrub leaves (19.63 and 369.08, respectively) were significant lower than that in branches (60.91 and 742.61) and roots (63.64 and 717.74) of shrubs, whereas the N:P mass ratio in shrub leaves (18.92) was significantly higher than in branches (12.51) and roots (13.52) of shrubs. However, there was no significant difference in the $C: N, C: P$ and $N: P$ mass ratios between aboveground and belowground herbs. In contrast, no significant differences were found in the $\mathrm{N}$ concentrations in the different soil layer. The highest $\mathrm{C}$ and $\mathrm{P}$ concentrations were in the surface 0-10 cm soil layer, and the values significant decreased with soil depth (Table 3 ). The C:N, C:P and N:P ratios did not change significantly with soil depths.

$\mathrm{C}, \mathrm{N}$ and $\mathrm{P}$ storage in the Chinese cork oak ecosystem were 163.76, 18.54 and 2.50 tha $^{-1}$, respectively. The $\mathrm{C}$ storage distribution among different tree components was in the following order: stem wood $>$ roots $>$ branches $>$ stem bark $>$ leaves. Whereas, the order was stem wood $>$ roots $>$ leaves $>$ stem bark $>$ branches for the $\mathrm{N}$ storage distribution, and stem wood $>$ roots $>$ branches $>$ leaves $>$ stem bark for the $\mathrm{P}$ storage distribution (Table 3). C, N and P storage in tree accounted $36.14 \%, 6.03 \%$, and $0.23 \%$ of the total ecosystem $\mathrm{C}, \mathrm{N}$, and $\mathrm{P}$ pools, respectively. The $\mathrm{C}, \mathrm{N}$, and $\mathrm{P}$ storage in the shrub, herb and litter pools accounted $2.10 \%, 1.19 \%$ and $0.03 \%$ of the total ecosystem $\mathrm{C}, \mathrm{N}$, and $\mathrm{P}$ pools, respectively. Soil $(0-100 \mathrm{~cm})$ contained the largest amount of $\mathrm{C}, \mathrm{N}$, and $\mathrm{P}$ storage, accounting for $61.76 \%, 92.78 \%$ and $99.72 \%$ of total ecosystem $\mathrm{C}, \mathrm{N}$, and $\mathrm{P}$ pools, respectively. $\mathrm{C}$ and $\mathrm{P}$ storage in the $0-50 \mathrm{~cm}$ soil depthswere significantly greater than that in deeper soil, accounting for $61.35 \%$ and $60.02 \%$ of the entire soil profile $(0-100 \mathrm{~cm})$; whereas, $\mathrm{N}$ storage between 0 and $50 \mathrm{~cm}$ was almost equal to that in deeper soil, accounting for $47.40 \%$ of the entire soil profile $(0-100 \mathrm{~cm})$. 
Table 3. $\mathrm{C}, \mathrm{N}$ and $\mathrm{P}$ concentrations and storage distribution of a Chinese cork oak forest in the south slope of the Qinling Mountains, China.

\begin{tabular}{|c|c|c|c|c|c|c|c|}
\hline \multirow[b]{2}{*}{ Layer } & \multirow[b]{2}{*}{ Component } & \multicolumn{2}{|c|}{$\mathbf{C}$} & \multicolumn{2}{|c|}{$\mathbf{N}$} & \multicolumn{2}{|c|}{$\mathbf{P}$} \\
\hline & & $\begin{array}{c}\text { Concentration } \\
\left(\mathrm{g} \mathrm{kg}^{-1}\right) \\
\end{array}$ & Storage (t ha $\left.{ }^{-1}\right)$ & $\begin{array}{c}\text { Concentration } \\
\left(\mathrm{g} \mathrm{kg}^{-1}\right) \\
\end{array}$ & Storage $\left(\mathrm{kg} \mathrm{ha}^{-1}\right)$ & $\begin{array}{c}\text { Concentration } \\
\left(\mathrm{g} \mathrm{kg}^{-1}\right) \\
\end{array}$ & Storage $\left(\mathrm{kg} \mathrm{ha}^{-1}\right)$ \\
\hline \multirow[t]{6}{*}{ Tree } & Stem wood & $433.28 \pm 9.43 c$ & $28.68 \pm 2.80 \mathrm{a}$ & $2.63 \pm 0.24 c$ & $174.11 \pm 16.98 \mathrm{a}$ & $0.35 \pm 0.06 \mathrm{~b}$ & $23.17 \pm 2.26 \mathrm{a}$ \\
\hline & Stem bark & $454.60 \pm 2.20 b$ & $6.58 \pm 0.51 c$ & $5.05 \pm 0.10 \mathrm{~b}$ & $73.11 \pm 5.66 \mathrm{~b}$ & $0.29 \pm 0.01 b$ & $4.20 \pm 0.32 c$ \\
\hline & Branches & $433.81 \pm 1.36 \mathrm{c}$ & $7.07 \pm 0.72 \mathrm{c}$ & $4.50 \pm 0.02 b c$ & $73.36 \pm 7.42 b$ & $0.62 \pm 0.08 b$ & $10.11 \pm 1.02 b$ \\
\hline & Leaves & $483.07 \pm 2.59 \mathrm{a}$ & $1.94 \pm 0.15 \mathrm{c}$ & $19.31 \pm 1.19 \mathrm{a}$ & $77.48 \pm 5.99 b$ & $1.26 \pm 0.16 \mathrm{a}$ & $5.06 \pm 0.39 c$ \\
\hline & Root & $441.96 \pm 4.03 b c$ & $14.92 \pm 1.18 b$ & $4.54 \pm 0.06 b c$ & $153.25 \pm 12.17 \mathrm{a}$ & $0.39 \pm 0.02 b$ & $13.17 \pm 1.04 b$ \\
\hline & Subtotal & & $59.19 \pm 5.31$ & & $551.31 \pm 47.76$ & & $55.70 \pm 4.99$ \\
\hline \multirow[t]{4}{*}{ Shrub } & Leaves & $459.12 \pm 4.96 \mathrm{a}$ & $0.09 \pm 0.02 b$ & $24.08 \pm 0.81 \mathrm{a}$ & $4.60 \pm 0.90 \mathrm{a}$ & $1.30 \pm 0.06 \mathrm{a}$ & $0.25 \pm 0.05 \mathrm{a}$ \\
\hline & Branch & $449.30 \pm 5.89 a$ & $0.37 \pm 0.07 \mathrm{ab}$ & $8.20 \pm 0.60 \mathrm{~b}$ & $6.80 \pm 1.34 \mathrm{a}$ & $0.69 \pm 0.06 b$ & $0.57 \pm 0.11 \mathrm{ab}$ \\
\hline & Root & $428.63 \pm 5.70 b$ & $0.59 \pm 0.17 \mathrm{a}$ & $7.85 \pm 0.93 b$ & $10.84 \pm 3.06 \mathrm{a}$ & $0.85 \pm 0.11 b$ & $1.18 \pm 0.33 \mathrm{a}$ \\
\hline & Subtotal & & $1.06 \pm 0.22$ & & $22.24 \pm 4.36$ & & $2.00 \pm 0.42$ \\
\hline \multirow[t]{3}{*}{ Herb } & Aboveground & $428.73 \pm 6.44 a$ & $0.08 \pm 0.01 \mathrm{a}$ & $14.83 \pm 0.85 \mathrm{a}$ & $2.81 \pm 0.45 \mathrm{a}$ & $1.34 \pm 0.08 \mathrm{a}$ & $0.25 \pm 0.04 \mathrm{a}$ \\
\hline & Belowground & $262.03 \pm 13.08 b$ & $0.11 \pm 0.03 \mathrm{a}$ & $7.61 \pm 0.40 \mathrm{~b}$ & $3.14 \pm 0.91 \mathrm{a}$ & $1.02 \pm 0.15 \mathrm{a}$ & $0.42 \pm 0.12 \mathrm{a}$ \\
\hline & Subtotal & & $0.19 \pm 0.04$ & & $5.95 \pm 1.14$ & & $0.67 \pm 0.14$ \\
\hline Litter & & $364.17 \pm 10.69$ & $2.18 \pm 0.44$ & $12.49 \pm 0.21$ & $74.88 \pm 15.20$ & $0.97 \pm 0.07$ & $5.82 \pm 1.18$ \\
\hline \multirow[t]{6}{*}{ Soil } & $0-10 \mathrm{~cm}$ & $16.63 \pm 1.19 \mathrm{a}$ & $18.05 \pm 1.86 \mathrm{~b}$ & $1.69 \pm 0.21 \mathrm{a}$ & $1.83 \pm 0.25 \mathrm{tha}^{-1} \mathrm{~b}$ & $0.43 \pm 0.11 \mathrm{a}$ & $0.46 \pm 0.11 \mathrm{tha}^{-1} \mathrm{~b}$ \\
\hline & $10-20 \mathrm{~cm}$ & $10.12 \pm 1.41 b c$ & $11.57 \pm 2.05 b$ & $1.47 \pm 0.27 \mathrm{a}$ & $1.68 \pm 0.34 \mathrm{tha}^{-1} \mathrm{~b}$ & $0.29 \pm 0.06 \mathrm{ab}$ & $0.33 \pm 0.07 \mathrm{tha}^{-1} \mathrm{~b}$ \\
\hline & $20-30 \mathrm{~cm}$ & $10.31 \pm 0.64 b$ & $11.54 \pm 0.81 b$ & $1.42 \pm 0.29 \mathrm{a}$ & $1.64 \pm 0.38 \mathrm{tha}^{-1} \mathrm{~b}$ & $0.27 \pm 0.02 \mathrm{ab}$ & $0.30 \pm 0.02 \mathrm{tha}^{-1} \mathrm{~b}$ \\
\hline & $30-50 \mathrm{~cm}$ & $8.63 \pm 1.34 b c$ & $20.89 \pm 3.77 b$ & $1.35 \pm 0.33 \mathrm{a}$ & $3.33 \pm 0.87 \mathrm{tha}^{-1} \mathrm{~b}$ & $0.16 \pm 0.03 b$ & $0.38 \pm 0.06 \mathrm{tha}^{-1} \mathrm{~b}$ \\
\hline & $50-100 \mathrm{~cm}$ & $5.76 \pm 0.53 c$ & $39.10 \pm 6.44 a$ & $1.26 \pm 0.37 \mathrm{a}$ & $9.41 \pm 3.19 \mathrm{tha}^{-1} \mathrm{a}$ & $0.16 \pm 0.03 b$ & $0.96 \pm 0.13 \mathrm{tha}^{-1} \mathrm{a}$ \\
\hline & Subtotal & & $101.14 \pm 11.03$ & & $17.89 \pm 4.92 \mathrm{tha}^{-1}$ & & $2.43 \pm 0.20 \mathrm{t} \mathrm{ha}^{-1}$ \\
\hline Total ecosystem & & $163.76 \pm 11.25$ & & $18.54 \pm 4.96 \mathrm{t} \mathrm{ha}^{-1}$ & & $2.50 \pm 0.21 \mathrm{t} \mathrm{ha}^{-1}$ & \\
\hline
\end{tabular}

Data is reported as mean \pm standard error $(n=3)$; within a column, values followed by the same lowercase letter indicate that they did not differ significantly within the same layer $(p<0.05)$. 


\section{Discussion}

Allometric equations are crucial in order to accurately estimate forest biomass for $\mathrm{C}$ accounting. A number of previous studies demonstrated that power function allometric equations based on $\mathrm{DBH}$ or squared DBH multiplied by $\mathrm{H}$ can be used to estimate tree biomass [29,35]. Allometric equations based on DBH are recommended because the measurement of $\mathrm{H}$ is time-consuming and less accurate than DBH $[19,34,40,41]$. In this study, we observed that DBH was the only significant parameter for bark, leaf, and root components; whereas, the squared $\mathrm{DBH}$ multiplied by $\mathrm{H}$ as the significant parameter for stem wood. Different models (Table 1) were used to estimate biomass distribution for Chinese cork oak in China due to various biotic and abiotic environmental factors. However, there was no significant difference in tree components biomass estimation, with the exception of roots, among all the available allometric equations. In some cases the power function failed, and then transformed models were needed to develop significant allometric equations for different tree species, locations, and specific-components [7,25,27,28,42-47].

The biomass distribution among tree components was as follows: stem wood $>$ roots $>$ branches $>$ stem bark $>$ leaves. Our findings were similar to the previous reports for Chinese cork oak in the temperate region of China [27-29]. However, the different biomass distribution also observed for Chinese cork oak. For example, the biomass distribution of a 20-year-old Chinese cork oak forest was distributed as follows: stem wood $>$ branches $>$ roots $>$ stem bark $>$ leaves at; while that in 30- and 40-year-old in hilly region of Taihang Mountain, the distribution was stem wood $>$ stem bark $>$ branches $>$ roots $>$ leaves at [48]. The total Chinese cork oak tree biomass was $158.84 \mathrm{t} \mathrm{ha}^{-1}$ in the Baotianman Natural Reserve, Henan Province [27], $134.75 \mathrm{t} \mathrm{ha}^{-1}$ in the south slope of the Qinling Mountains of the present study, $79.80 \mathrm{t} \mathrm{ha}^{-1}$ in the Xiaolong Mountains, Gansu Province [28] and $53.64 \mathrm{t} \mathrm{ha}^{-1}$ in the Xishan Mountains, Beijing [29]. These obvious differences were mainly caused by age, tree density, and climate factors. Zhao et al. [48] reported that in a hilly region of Taihang Mountain, tree biomass significantly increased from $131.65 \mathrm{t} \mathrm{ha}^{-1}$ in a 20 year old stand to 202.96 and $291.15 \mathrm{tha}^{-1}$ in 30 and 40 years old stands, respectively.

The nutrient concentrations among plant components were significantly different. The concentrations of $\mathrm{C}, \mathrm{N}$ and $\mathrm{P}$ in tree leaves were the highest, but the lowest values of $\mathrm{C}$ and $\mathrm{N}$ were observed in tree stems. In addition to $\mathrm{C}, \mathrm{N}$ and $\mathrm{P}$, the highest mobile nutrient concentrations, such as $\mathrm{Mg}, \mathrm{K}$, and $\mathrm{Mn}$, were also detected in the leaves of oak forests in Spain [19]. Moreover, the N, P, and K concentrations were the highest in spring and then decreased throughout the vegetative period [19]. Similarly, the highest concentrations were in shrub leaves, but the lowest values were in shrub roots. The $\mathrm{C}, \mathrm{N}$ and $\mathrm{P}$ concentrations in aboveground portion of herb were higher than in the belowground portion. The leaves $\mathrm{N}: \mathrm{P}$ ratio, which is relatively easy to determine, has been widely used to indicate limitations in soil $\mathrm{N}$ $(\mathrm{N}: \mathrm{P}<14)$ and soil $\mathrm{P}(\mathrm{N}: \mathrm{P}>16)[49,50]$. The leaf $\mathrm{N}\left(19.31 \mathrm{~g} \mathrm{~kg}^{-1}\right), \mathrm{P}\left(1.26 \mathrm{~g} \mathrm{~kg}^{-1}\right)$ concentrations, and $\mathrm{N}: \mathrm{P}$ ratio (16.10) of Chinese cork oak forests in the present study were similar with the average values of leaves $\mathrm{N}\left(18.33 \mathrm{~g} \mathrm{~kg}^{-1}\right)$ and $\mathrm{P}\left(1.18 \mathrm{~g} \mathrm{~kg}^{-1}\right)$ concentrations and the $\mathrm{N}: \mathrm{P}$ ratio (16.56) in China [51]. Moreover, the N:P ratio of shrub leaves was also higher than 16. Therefore, soil $\mathrm{P}$ is a limiting nutrient in this study area for the growth demands of Chinese cork oak forests. In contrast, the leaves N:P ratios of sharptooth oak, Chinese pine, and Armand pine indicated that there is soil $\mathrm{N}$ limitation in the Qinling Mountains [52]. However, the nutrient concentrations in live leaves decreased 
and the N:P ratio increased during the growing seasons were observed in a Mediterranean cork oak forest in southwestern Spain [26]. Moreover, the leaf N and P concentrations of Chinese cork oak forests also decreased during stand development. It was shown that there is an disconnect bewteen soil P supply and plant growth demand indicated by an increased N:P ratio from 13.84 in 20-year-old stand to 16.05 and 19.75 in 30- and 40-year-old stands, respectively, in a hilly region of the Taihang Mountains [48]. Therefore, quantifying soil nutrient limitation by only using the leaf N:P ratio presents challenges because of the limited amount of data and only a partial understanding of the processes involved [50,53]. Although significant differences in leaves $\mathrm{N}$ and $\mathrm{P}$ concentrations were detected across all Quercus species in China, leaf N:P ratio (13.96) was well constrained to a relatively stable range for Quercus species and was less influenced by environmental variables across China [51].

Abundant precipitation, full sunshine and nutrient-rich soil were considered to be suitable for supporting plant growth in the southern slope of the Qinling Mountains [52]. C, N, and P were enriched at $0-10 \mathrm{~cm}$ soil depth, while $\mathrm{C}$ and $\mathrm{P}$ decreased with an increase in soil depth. However, $\mathrm{N}$ showed a stable trend. C, N, and P concentrations of $0-10 \mathrm{~cm}$ soil depth in this study area $\left(16.63,1.69\right.$ and $0.43 \mathrm{~g} \mathrm{~kg}^{-1}$, respectively) were higher than the mean values (12.28, 0.94 and $0.38 \mathrm{~g} \mathrm{~kg}^{-1}$, respectively) of soils in China. As a consequence, the C:N, C:P and N:P (10.55, 51.51 and 4.59 in molar, respectively) ratios of 0-10 cm soil depth in this study area were smaller than those mean values $(14.4,136$ and 9.3, respectively) of soils in China [54]. C, N, and P concentrations increased during stand development of Chinese cork oak forests in the hilly region of the Taihang Mountains, possibly due to a larger accumulation of organic matter in older stands [48]. Under Mediterranean climate conditions in Mainland Spain, the soil C storage of cork oak forests was favored by large organic matter inputs, high soil clay contents, a calcium-saturated soil matrix and reduced summer aridity [23].

The proportion of stem to total tree biomass was around $60 \%$ in this study. The highest percentage was $73 \%$ for four Mediterranean oak forests in Spain [19]. The proportion of stem to total tree biomass has been used to infer the light conditions, soil nutrient and age stage at study sites [35,36]. For example, the ratios in Chinese pine were $46.9 \%, 72.2 \%, 70.6 \%$ and $70.7 \%$ for young, middle-aged, immature, and mature stands, respectively [34]. Although the low percentage of nutrients accumulated in the leaves because leaf biomass represents only around 3\% of the total, the amount of nutrients accumulated in leaves was of great importance because the nutrients were subject to internal annual cycles within the tree, and some of them return to the soil in the form of leaf litter [19]. At the same time, root biomass accounted for a large proportion of the total tree biomass. The ratio of below- to aboveground biomass was 0.33 for Chinese cork oak forests in this study. The ratio value was $0.28,0.29$ and 0.23 for the Baotianman Natural Reserve of Henan Province [27], the Xiaolong Mountainsof Gansu Province [28], and the Xishan Mountains of Beijing [29], respectively. In contrast to the result [55] that there is a relatively constant ratio of below- to aboveground biomass during stand development globally, Zhao et al. [48] found that the ratio decreased during stand development, from 0.23 in a 20 -year-old stand to 0.16 and 0.13 in 30- and 40-year-old stands, respectively, in a hilly region of the Taihang Mountains. The decreased below- to aboveground biomass ratio may demonstrate different strategies in nutrient cycling and water uptake potential [1]. Our study agrees with previous studies that soil is the largest $\mathrm{C}$ and nutrient element storage component, followed by tree, understory, and litter [21]. Soil C, $\mathrm{N}$, and $\mathrm{P}$ storage were 1.62-, 27.52- and 34.71-fold higher than vegetation $\mathrm{C}, \mathrm{N}$, and P storage. In addition, soil $\mathrm{C}$ storage was higher in the topsoil than in deeper soil owing to soil organic matter is the 
main source of $\mathrm{C}$ stored in topsoil. Moreover, soil organic matter is essential to ecosystem productivity and regeneration. Recently, many studies have focused on biomass, $\mathrm{C}$, and nutrient storage during stand development [1,7,34-36,48,55]. These studies provided a comprehensive understanding of the importance of considering the succession development of forest ecosystem $\mathrm{C}$ pools and the interaction with other nutrient elements, especially when estimating $C$ sink potential over a life cycle. Because human disturbances can have huge impacts on certain age stage forests, we only selected 30-year-old Chinese cork oak stands with little or no human disturbance to describe the basic characteristics of biomass, $\mathrm{C}$ and nutrient storage distribution. Therefore, future studies should focus on improving our understand of the effects of age and disturbance in biomass, $\mathrm{C}$ concentrations and stocks for devising optimum forest management strategies aimed at mitigating climate change.

\section{Conclusions}

In this study, we presented the basic $\mathrm{C}, \mathrm{N}$ and $\mathrm{P}$ storage distribution patterns among trees, shrubs, herbs, litter, and soil $(0-100 \mathrm{~cm})$ in a 30-year-old Chinese cork oak forest in the south slope of the Qinling Mountains, China. The biomass of tree components can be better predicted from allometric equations using DBH as the independent variable. There was no significant difference in various tree components biomass estimations, with the exception of roots, between different Chinese cork oak allometric equations developed from different sites. Stems and roots were the main proportion of total tree biomass. The proportion of stem to total tree biomass was around $60 \%$ and the ratio of below- to aboveground biomass was 0.33 . There were significant differences in $\mathrm{C}, \mathrm{N}$ and $\mathrm{P}$ concentrations between plant components. Plant leaves had the highest $\mathrm{C}, \mathrm{N}$, and $\mathrm{P}$ concentrations than other plant components. The N:P ratio was similar to the national level and indicated soil $\mathrm{P}$ limitation. However, $\mathrm{C}, \mathrm{N}$ and $\mathrm{P}$ concentrations of the $0-10 \mathrm{~cm}$ soil depth were higher than those mean values of soils in China. C, N, and P storage of this Chinese cork oak ecosystem were 163.76, 18.54 and $2.50 \mathrm{t} \mathrm{ha}^{-1}$, respectively. Soil was the largest $\mathrm{C}$ and nutrient element storage component, followed by trees. $\mathrm{C}, \mathrm{N}$, and $\mathrm{P}$ stocks in shrubs, herbs, and litter contributed only little to ecosystem C, N and P stocks. This study demonstrated that large-scale Chinese cork oak forests in the Qinling Mountains play an important role in $\mathrm{C}$ sequestration under NFP program. Furthermore, we suggest that further research on human-caused, natural disturbance and other influence factors on the continuous accumulation of $\mathrm{C}$ in both the plants and soils are especially critical for developing recommendations on appropriate forest management practices under the NFP program.

\section{Acknowledgments}

This research was supported by the National Nature Science Foundation of China (No. 41201088 and 41371506), the Strategic Priority Research Program and West Light Foundation of The Chinese Academy of Sciences (XDA05050203 and K318021304), the Doctoral Fund of Ministry of Education of China (20120204120014), Specialized Research Fund for the Doctoral Program of Higher Education (2014YB056) and Institute of Soil and Water Conservation Funding (A315021380). 


\section{Author Contributions}

The paper was written by Yang Cao with a contribution by Yunming Chen. Yunming Chen conceptualized the research design and site selection, and submitted the article. Yang Cao conducted field data collection and data processing.

\section{Conflicts of Interest}

The authors declare no conflict of interest.

\section{References}

1. Laclau, P. Biomass and carbon sequestration of ponderosa pine plantations and native cypress forests in northwest Patagonia. For. Ecol. Manag. 2003, 180, 317-333.

2. Chen, X.G.; Zhang, X.Q.; Zhang, Y.P.; Wan, C.B. Carbon sequestration potential of the stands under the grain for green program in Yunnan province, China. For. Ecol. Manag. 2009, 258, 199-206.

3. Bonner, M.T.L.; Schmidt, S.; Shoo, L.P. A meta-analytical global comparison of aboveground biomass accumulation between tropical secondary forests and monoculture plantations. For. Ecol. Manag. 2013, 291, 73-86.

4. He, Y.J.; Qin, L.; Li, Z.Y.; Liang, X.Y.; Shao, M.X.; Tan, L. Carbon storage capacity of monoculture and mixed-species plantations in subtropical China. For. Ecol. Manag. 2013, 295, 193-198.

5. Zeng, X.H.; Zhang, W.J.; Liu, X.P.; Cao, J.S.; Shen, H.T.; Zhao, X.; Zhang, N.N.; Bai, Y.R.; Yi, M. Change of soil organic carbon after cropland afforestation in "Beijing-Tianjin sandstorm source control" program area in China. Chin. Geogra. Sci. 2014, 24, 461-470.

6. Zhou, W.M.; Lewis, B.J.; Wu, S.N.; Yu, D.P.; Zhou, L.; Wei, Y.W.; Dai, L.M. Biomass carbon storage and its sequestration potential of afforestation under natural forest protection program in China. Chin. Geogra. Sci. 2014, 24, 406-413.

7. Li, T.; Liu, G. Age-related changes in carbon accumulation and allocation in plants and soil of a black locust forest on the loess plateau. Chin. Geogra. Sci. 2014, 24, 414-422.

8. Deng, L.; Liu, G.B.; Shangguan, Z.P. Land-use conversion and changing soil carbon stocks in China's "grain-for-green" program: A synthesis. Glob. Change Biol. 2014, 20, 3544-3556.

9. Chang, R.; Fu, B.; Liu, G.; Liu, S. Soil carbon sequestration potential for "grain for green" project in loess plateau, China. Environ. Manag. 2011, 48, 1158-1172.

10. Wei, Y.W.; Yu, D.P.; Lewis, B.J.; Zhou, L.; Zhou, W.M.; Fang, X.M.; Zhao, W.; Wu, S.N.; Dai, L.M. Forest carbon storage and tree carbon pool dynamics under natural forest protection program in northeastern China. Chin. Geogra. Sci. 2014, 24, 397-405.

11. Hu, H.; Liu, G. Carbon sequestration of China's national natural forest protection project. Acta Ecol. Sin. 2006, 26, 291-296.

12. Fang, J.; Brown, S.; Tang, Y.; Nabuurs, G.-J.; Wang, X.; Shen, H. Overestimated biomass carbon pools of the northern mid- and high latitude forests. Clim. Chang. 2006, 74, 355-368.

13. Liu, G.; Fu, B.; Fang, J. Carbon dynamics of Chinese forests and its contribution to global carbon balance. Acta Ecol. Sin. 2000, 20, 733-740. 
14. Zhao, M.; Zhou, G. Forest inventory data (FID)-based biomass models and their prospects. Chin. J. Appl. Ecol. 2004, 15, 1468-1472.

15. Wei, Y.W.; Li, M.H.; Chen, H.; Lewis, B.J.; Yu, D.P.; Zhou, L.; Zhou, W.M.; Fang, X.M.; Zhao, W.; Dai, L.M. Variation in carbon storage and its distribution by stand age and forest type in boreal and temperate forests in northeastern China. PLOS ONE 2013, 8, doi:10.1371/journal.pone.0072201.

16. Du, L.; Zhou, T.; Zou, Z.H.; Zhao, X.; Huang, K.C.; Wu, H. Mapping forest biomass using remote sensing and national forest inventory in China. Forests 2014, 5, 1267-1283.

17. Guyette, R.P.; Dey, D.C.; Stambaugh, M.C. The temporal distribution and carbon storage of large oak wood in streams and floodplain deposits. Ecosystems 2008, 11, 643-653.

18. Borges, J.G.; Oliveira, A.C.; Costa, M.A. A quantitative approach to cork oak forest management. For. Ecol. Manag. 1997, 97, 223-229.

19. Santa-Regina, I. Biomass estimation and nutrient pools in four Quercus pyrenaica in sierra de gata mountains, Salamanca, Spain. For. Ecol. Manag. 2000, 132, 127-141.

20. Gardiner, E.S.; Hodges, J.D. Growth and biomass distribution of cherrybark oak (Quercus pagoda raf.) seedlings as influenced by light availability. For. Ecol. Manag. 1998, 108, 127-134.

21. Vallet, P.; Meredieu, C.; Seynave, I.; Belouard, T.; Dhote, J.F. Species substitution for carbon storage: Sessile oak versus corsican pine in France as a case study. For. Ecol. Manag. 2009, 257, 1314-1323.

22. Lopez, B.C.; Sabate, S.; Gracia, C.A. Thinning effects on carbon allocation to fine roots in a Quercus ilex forest. Tree Physiol. 2003, 23, 1217-1224.

23. Gonzalez, I.G.; Corbi, J.M.G.; Cancio, A.F.; Ballesta, R.J.; Cascon, M.R.G. Soil carbon stocks and soil solution chemistry in quercus ilex stands in mainland Spain. Eur. J. For. Res. 2012, 131, 1653-1667.

24. Cerasoll, S.; Scartazza, A.; Brugnoli, E.; Chaves, M.M.; Pereira, J.S. Effects of partial defoliation on carbon and nitrogen partitioning and photosynthetic carbon uptake by two-year-old cork oak (Quercus suber) saplings. Tree Physiol. 2004, 24, 83-90.

25. Fonseca, T.J.F.; Parresol, B.R. A new model for cork weight estimation in northern Portugal with methodology for construction of confidence intervals. For. Ecol. Manag. 2001, 152, 131-139.

26. Andivia, E.; Fernandez, M.; Vazquez-Pique, J.; Gonzalez-Perez, A.; Tapias, R. Nutrients return from leaves and litterfall in a mediterranean cork oak (Quercus suber L.) forest in southwestern Spain. Eur. J. For. Res. 2010, 129, 5-12.

27. Liu, Y.; Wu, M.; Guo, Z.M.; Jiang, Y.; Liu, S. Biomass and net productivity of Quercus variabilis forest in Baotianman natural reserve. Chin. J. Appl. Ecol. 1998, 9, 569-574.

28. Cheng, T.; Ma, Q.; Feng, Z.; Luo, X. Research on forest biomass in Xiaolong Mountains, Gansu province. J. Beijing For. Univ. 2007, 29, 31-36.

29. Bao, X.; Chen, L.; Chen, Q.; Ren, J.; Hu, Y.; Li, Y. The biomass of planted oriental oak (Quercus variabilis) forest. Acta Phytoecol. et Geobot. Sin. 1984, 8, 313-320.

30. Zhang, W.; Lu, Z. A study on the biological and ecological property and geographical distribution of Quercus variabilis population. Acta Bot. Boreali-Occidential Sin. 2001, 22, 1093-1101.

31. Ran, R.; Zhang, W.; Zhou, J.; He, J. Effects of thinning intensities on population regeneration of natural Quercus variabilis forest on the south slope of Qinling Mountains. Chin. J. Appl. Ecol. 2014, $25,695-701$. 
32. Ran, R.; Zhang, W.; Zhou, J.; He, J. Effects of thinning intensity on the seed bank and seedling growth of Quercus variabilis on the south slope of Qinling mountains, northwest China. Chin. J. Appl. Ecol. 2013, 24, 1494-1500.

33. Yi, Q.Z.; Zhang, W.; Tang, D. Effects of reserved sprout number per stump on sprout development and biomass accumulation of Quercus variabilis. Sci. Silvae Sin. 2013, 7, 34-39.

34. Zhao, J.L.; Kang, F.F.; Wang, L.X.; Yu, X.W.; Zhao, W.H.; Song, X.S.; Zhang, Y.L.; Chen, F.; Sun, Y.; He, T.F.; et al. Patterns of biomass and carbon distribution across a chronosequence of Chinese pine (Pinus tabulaeformis) forests. PLOS ONE 2014, 9, doi:10.1371/journal.pone.0094966.

35. Li, H.; Li, C.; Zha, T.; Liu, J.; Jia, X.; Wang, X.; Chen, W.; He, G. Patterns of biomass allocation in an age-sequence of secondary Pinus bungeana forests in China. For. Chron. 2014, 90, 169-176.

36. Noh, N.J.; Son, Y.; Kim, R.H.; Seo, K.W.; Koo, J.W.; Park, I.H.; Lee, Y.J.; Lee, K.H.; Son, Y.M. Biomass accumulations and the distribution of nitrogen and phosphorus within three Quercus acutissima stands in central Korea. J. Plant Biol. 2007, 50, 461-466.

37. Parkinson, J.; Allen, S. A wet oxidation procedure suitable for the determination of nitrogen and mineral nutrients in biological material. Commun. Soil Sci. Plant Anal. 1975, 6, 1-11.

38. Nelson, D.W.; Sommers, L.E.; Sparks, D.; Page, A.; Helmke, P.; Loeppert, R.; Soltanpour, P.; Tabatabai, M.; Johnston, C.; Sumner, M. Total carbon, organic carbon, and organic matter. Methods of Soil Analysis. Part 3-Chemical Methods, SSSA Book Series 5.3; Soil Science Society of America, American Society of Agronomy: Madison, WI, UAS, 1996; pp. 961-1010.

39. Bremner, J.M. Total Nitrogen. In Methods of Soil Analysis. Part 2. Chemical and Microbiological Properties, Agronomy Monograph 9.2; SSSA: Madison, WI, USA, 1965; pp. 1149-1178.

40. Peichl, M.; Arain, M.A. Allometry and partitioning of above- and belowground tree biomass in an age-sequence of white pine forests. For. Ecol. Manag. 2007, 253, 68-80.

41. Gower, S.T.; Kucharik, C.J.; Norman, J.M. Direct and indirect estimation of leaf area index, fAPAR, and net primary production of terrestrial ecosystems. Remote Sens. Environ. 1999, 70, $29-51$.

42. Basuki, T.M.; van Laake, P.E.; Skidmore, A.K.; Hussin, Y.A. Allometric equations for estimating the above-ground biomass in tropical lowland dipterocarp forests. For. Ecol. Manag. 2009, 257, $1684-1694$.

43. Makungwa, S.D.; Chittock, A.; Skole, D.L.; Kanyama-Phiri, G.Y.; Woodhouse, I.H. Allometry for biomass estimation in Jatropha trees planted as boundary hedge in farmers' fields. Forests $\mathbf{2 0 1 3}$, 4, 218-233.

44. Sitoe, A.A.; Mandlate, L.J.C.; Guedes, B.S. Biomass and carbon stocks of Sofala bay mangrove forests. Forests 2014, 5, 1967-1981.

45. Ritchie, M.W.; Zhang, J.W.; Hamilton, T.A. Aboveground tree biomass for Pinus ponderosa in northeastern California. Forests 2013, 4, 179-196.

46. Beets, P.N.; Kimberley, M.O.; Oliver, G.R.; Pearce, S.H.; Graham, J.D.; Brandon, A. Allometric equations for estimating carbon stocks in natural forest in New Zealand. Forests 2012, 3, 818-839.

47. Mate, R.; Johansson, T.; Sitoe, A. Biomass equations for tropical forest tree species in Mozambique. Forests 2014, 5, 535-556.

48. Zhao, Y.; Wang, P.; Fan, W.; Zhu, Y. Nutrient cycling in Quercus varlabilis plantations of different ages classes in hilly region of Taihang mountain. Sci. Soil Water Conserv. 2009, 7, 66-71. 
49. Gusewell, S. N:P ratios in terrestrial plants: Variation and functional significance. New Phytol. 2004, 164, 243-266.

50. Townsend, A.R.; Cleveland, C.C.; Asner, G.P.; Bustamante, M.M.C. Controls over foliar N:P ratios in tropical rain forests. Ecol. 2007, 88, 107-118.

51. Wu, T.G.; Dong, Y.; Yu, M.K.; Wang, G.G.; Zeng, D.H. Leaf nitrogen and phosphorus stoichiometry of Quercus species across China. For. Ecol. Manag. 2012, 284, 116-123.

52. Liu, G.; Zhao, S.; Tu, X. Distributional characteristics on biomass and nutrient elements of pine-oak forest belt in Mt. Qinling. Sci. Silvae Sin. 2001, 37, 28-36.

53. Goll, D.S.; Brovkin, V.; Parida, B.R.; Reick, C.H.; Kattge, J.; Reich, P.B.; van Bodegom, P.M.; Niinemets, U. Nutrient limitation reduces land carbon uptake in simulations with a model of combined carbon, nitrogen and phosphorus cycling. Biogeosciences 2012, 9, 3547-3569.

54. Tian, H.Q.; Chen, G.S.; Zhang, C.; Melillo, J.M.; Hall, C.A.S. Pattern and variation of C:N:P ratios in China's soils: A synthesis of observational data. Biogeochemistry 2010, 98, 139-151.

55. Yang, Y.; Luo, Y. Carbon:Nitrogen stoichiometry in forest ecosystems during stand development. Glob. Ecol. Biogeogr. 2011, 20, 354-361.

(C) 2015 by the authors; licensee MDPI, Basel, Switzerland. This article is an open access article distributed under the terms and conditions of the Creative Commons Attribution license (http://creativecommons.org/licenses/by/4.0/). 